\title{
TUNJANGAN PROFESI SEBAGAI UPAYA PENINGKATAN KOMPETENSI GURU UNTUK MEWUJUDKAN GURU PROFESIONAL
}

\author{
${ }^{1}$ Jimmi Yuliandri dan ${ }^{2}$ Tahrun \\ ${ }^{1}$ Guru Sekolah Dasar Negeri 12 Rambutan Banyuasin \\ ${ }^{2}$ Dosen Program Pascasarjana Universitas PGRI Palembang \\ e-mail: jimmippsmppgri2@gmail.com
}

\begin{abstract}
This research was conducted to reveal the improvement of teachers' competence who have received professional allowances in realizing professional teachers. The data were obtained through interviews, documentation and observation. Improving the teachers' competence is expected in order to improve the quality of education. Only then the professional teacher is capable of conducting learning and succeeding in bringing the learner into the world of life according to today's needs and challenges. Conversely, the unwillingness and inability of teachers to adjust their insight and competence with the demands of the development would be one of the obstacles to the achievement of educational and learning objectives.
\end{abstract}

Keywords: Professional Allowances, Improvement of Teachers' Competence, Professional Teacher

\section{PENDAHULUAN}

Penelitian ini berawal dari permasalahan yang hingga kini, baik dalam fakta maupun persepsi, masih banyak kalangan yang meragukan kompetensi guru, khususnya guru yang telah menerima tunjangan profesi, baik dalam bidang studi yang diajarkan maupun bidang lain yang mendukung terutama bidang didaktik dan metodik pembelajaran. Masalah semakin pelik, karena tidak sedikit anggaran yang dikeluarkan oleh pemerintah pusat maupun daerah untuk menyalurkan tunjangan profesi guru ini yang cenderung mengalami peningkatan setiap tahunnya. Namun kenyataannya, anggaran besar yang dikeluarkan setiap tahunnya ini tidak sebanding dengan peningkatan kompetensi guru-guru yang telah menerima tunjangan profesi ini. Padahal hakikatnya, tujuan utama pemerintah memberikan tunjangan profesi kepada guru adalah untuk meningkaktan kompetensi guru tersebut guna memperbaiki kualitas dan mutu pendidikan sehingga guru tersebut dapat dikatakan sebagai guru profesional.

Ilmu pengetahuan dan teknologi (IPTEK), baik sebagai substansi materi ajar maupun piranti penyelenggaraan pembelajaran akan terus berkembang. Dinamika inilah yang menuntut guru agar selalu meningkatkan dan menyesuaikan kompetensinya supaya mampu mengembangkan dan menyajikan materi pelajaran yang aktual dengan menggunakan berbagai pendekatan, metoda, dan teknologi pembelajaran terkini. Akibat dari masih banyaknya guru yang tidak menguasai kompetensi yang dipersyaratkan, ditambah 
dengan kurangnya kemampuan menggunakan TIK membawa dampak pada siswa paling tidak dalam dua hal. Pertama, siswa hanya terbekali dengan kompetensi yang telah usang. Akibatnya, produk sistem pendidikan dan pembelajaran tidak siap terjun ke dunia kehidupan nyata yang terus berubah. Kedua, pembelajaran yang diselenggarakan oleh guru juga kurang kondusif bagi tercapainya tujuan secara aktif, kreatif, efektif dan menyenangkan karena tidak didukung oleh penggunaan teknologi pembelajaran yang modern dan handal. Hal itu didasarkan pada kenyataan bahwa substansi materi pelajaran yang harus dipelajari oleh peserta didik terus berkembang baik volume maupun kompleksitasnya.

Sebagaimana ditekankan dalam prinsip percepatan belajar (accelerated learning), kecenderungan materi yang harus dipelajari peserta didik yang semakin hari semakin bertambah jumlah, jenis dan tingkat kesulitannya, menuntut dukungan strategi dan teknologi pembelajaran yang secara terus menerus disesuaikan pula agar pembelajaran dapat dituntaskan dalam interval waktu yang sama.

Reformasi pendidikan yang diamanatkan oleh Undang-Undang Nomor 20 tahun 2003 tentang Sistem Pendidikan Nasional, UndangUndang Nomor 14 tahun 2005 tentang Guru dan Dosen, dan Peraturan Pemerintah Nomor 19 tahun 2005 tentang Standar Nasional
Pendidikan menuntut reformasi guru untuk memilki kompetensi yang lebih tinggi, baik kompetensi pedagogik, kepribadian, profesional maupun sosial.

Berdasarkan paparan tersebut di atas, penelitian ini bermaksud mengungkap apa saja bentuk peningkatan kompetensi guru penerima tunjangan profesi di SD Negeri 3 Rambutan Kabupaten Banyuasin. Sekolah ini dipilih sebagai objek penelitian karena: 1) SD Negeri 3 Rambutan Kabupaten Banyuasin adalah sekolah yang lokasinya berdekatan dan persis di seberang sekolah tempat peneliti melaksanakan tugas mengajar sehari-hari, 2) dari 16 guru ASN (Aparatur Sipil Negara) yang ada pada SD 3 Rambutan kabupaten Banyuasin, 13 orang telah menerima tunjangan profesi dan memegang sertifikat pendidik, 3) SD Negeri 3 Rambutan Kabupaten Banyuasin adalah satu-satunya Sekolah Dasar (SD) yang terakreditasi "A" dari 23 sekolah dasar lainnya di kecamatan Rambutan. Penelitian ini dilakukan karena berdasarkan hasil penelitian Bank Dunia yang dirilis berbagai media beberapa waktu yang lalu seperti yang diungkap oleh Tobari (Sumatera Ekspres, 28 September 2016), Bank Dunia menemukan data bahwa tidak ada perbedaan yang signifikan dalam nilai uji kompetensi guru (UKG) guru yang telah sertifikasi atau menerima tunjangan profesi dengan guru yang belum menerima tunjangan profesi. Sedangkan 
hasil studi lain seperti yang diungkap oleh Uszaman (2014) menunjukkan bahwa peningkatan sertifikasi profesi guru yang diikuti dengan pemberian tunjangan profesi guru baru mampu meningkatkan kesejahteraan guru yang diukur, antara lain dengan berkurangnya proporsi guru yang memiliki pekerjaan tambahan. Akan tetapi, sertifikasi profesi belum terlihat dampaknya terhadap peningkatan kualitas proses pembelajaran yang diukur dengan kualitas subtansi pembelajaran maupun hasil belajar siswa yang dinilai dengan hasil ujian sekolah maupun ujian nasional.

\section{TUNJANGAN PROFESI}

Undang- Undang Nomor 14 Tahun 2005 tentang Guru dan Dosen mengamanatkan bahwa dalam melaksanakan tugas keprofesian, guru berhak memperoleh penghasilan di atas kebutuhan hidup minimum dan jaminan kesejahteraan sosial. Penghasilan di atas kebutuhan hidup minimum tersebut meliputi gaji pokok, tunjangan yangmelekat pada gaji, serta penghasilan lain berupa tunjangan profesi, tunjangan fungsional, tunjangan khusus dan maslahat tambahan yang terkait dengan tugasnya sebagai guru yang ditetapkan dengan prinsip penghargaan atas dasar prestasi.

Pemenuhan hak guru untuk memperoleh penghasilan didasari atas pertimbangan prestasi dan pengakuan atas profesionalitasnya. Dengan demikian, penghasilan dimaksud merupakan hak yang diterima oleh guru dalam bentuk finansial sebagai imbalan melaksanakan tugas keprofesian yang ditetapkan dengan prinsip penghargaan atas dasar prestasi dan mencerminkan martabat guru sebagai pendidik profesional.

Guru profesional dituntut oleh undangundang memilki kualifikasi akademik tertentu dengan empat kompetensi yaitu pedagogik, kepribadian, sosial, dan profesional akademik. Sertifikasi guru merupakan proses untuk memberikan sertifikat pendidik kepada mereka. Sertifikat pendidik dimaksud merupakan pengakuan negara atas derajat keprofesionalan guru.

Seiring dengan proses sertifikasi inilah, pemerintah memberikan tunjangan profesi kepada guru, Hal ini sesuai dengan UndangUndang Nomor 14 Tahun 2005 tentang Guru dan Dosen yang mengamanatkan bahwa "Pemerintah memberikan tunjangan profesi kepada guru yang telah memilki sertifikat pendidik yang diangkat oleh penyelenggara pendidikan dan/atau satuan pendidikan yang diselenggarakan oleh masyarakat".Pemberian tunjangan profesi ini diharapkan akan mampu mendorong dan memotivasi guru untuk terus meningkatkan kompetensi dan kinerja profesionalnya dalam melaksanakan tugas di 
sekolah sebagai pendidik, pengajar, pembimbing, pengarah, pelatih, dan penilai peserta didiknya.

Peraturan Pemerintah Nomor 41 Tahun 2009 mendefinisikan Tunjangan profesi adalah tunjangan yang diberikan kepada guru dan dosen yang memiliki sertifikat pendidik sebagai penghargaan atas profesionalitasnya. Sesuai Pasal 15 ayat (1) PP Nomor 74 Tahun 2008, Tunjangan profesi diberikan kepada guru yang memenuhi persyaratan sebagai berikut: 1) memiliki satu atau lebih sertifikat pendidik yang telah diberi satu nomor registrasi guru oleh Departemen, 2) memenuhi beban kerja sebagai guru, 3) mengajar sebagai guru mata pelajaran dan/atau guru kelas pada satuan pendidikan yang sesuai dengan peruntukan sertifikat pendidik yang dimilikinya, 4) terdaftar pada departemen sebagai guru tetap, 5) berusia paling tinggi 60 tahun, 6) Tidak terikat sebagai tenaga tetap pada instansi selain satuan pendidikan tempat bertugas.

Berdasarkan Pasal 7 Peraturan Pemerintah Nomor 41 Tahun 2009 tentang Tunjangan Profesi Guru dan Dosen, Tunjangan Khusus Guru dan Dosen, serta Tunjangan Kehormatan Profesor, diatur bahwa tunjangan profesi bagi guru diberikan terhitung mulai bulan Januari tahun berikutnya setelah yang bersangkutan mendapat Nomor Registrasi Guru dari Departemen. Hal ini dipertegas kembali pada Peraturan Menteri Keuangan No.164/PMK.05/2010 tentang Tata Cara Pembayaran Tunjangan Profesi Guru dan Dosen, Tunjangan Khusus Guru dan Dosen, serta Tunjangan Kehormatan Profesor pada Pasal 9 ayat (1) diatur bahwa Tunjangan Profesi Guru dimaksud terhitung mulai bulan Januari tahun berikutnya setelah yang bersangkutan mendapat Nomor Registrasi Guru dari Kementerian Kependidikan Nasional.Bagi guru PNS yang menduduki jabatan fungsional, TPG diberikan sebesar 1 (satu) kali gaji pokok PNS yang bersangkutan per bulan sesuai dengan PP 11 Tahun 2011 dan dikenakan pajak penghasilan sesuai dengan peraturan perundang-undangan di bidang perpajakan, dan diberikan selama guru yang bersangkutan masih melaksanakan tugas sebagai guru atau guru yang mendapat tugas tambahan sebagai pengawas satuan pendidikan dengan memenuhi semua persyaratan yang sesuai dengan ketentuan perundang-undangan yang berlaku. Sedangkan bagi guru tetap bukan PNS yang telah memiliki sertifikat pendidik tetapi belum memiliki jabatan fungsional guru, sesuai Permendiknas Nomor 72 tahun 2008, diberikan tunjangan profesi sebesar Rp1.500.000,00 (satu juta lima ratus ribu rupiah) setiap bulan, sampai dengan guru yang bersangkutan memperoleh jabatan fungsional guru. 
Program sertifikasi guru yang berujung pada pemberian tunjangan profesi kepada guru, diterapkan oleh pemerintah selain untuk meningkatkan kualitas kompetensi seorang guru dan meningkatkan kesejahteraan hidup guru, juga mengakui bahwa profesi guru setara dengan profesi lainnya, Imbalannya, guru akan mendapatkan satu kali gaji pokok dan pengakuan-pengakuan lainnya. Tentunya, program ini sangat menggiurkan bagi semua orang, khususya guru. Oleh karena itulah, begitu program sertifikasi diluncurkan para guru termotivasi mendapatkan kesempatan mengikuti program tersebut. Berbagai cara pun ditempuh agar dapat lulus seleksi sertifikasi (Saroni, 2001). Namun konsekuensinya, guru diharapkan semakin profesional dalam melaksanakan tugasnya. Guru hendaknya tak lagi tertinggal di bidangnya. Guru dari hari ke hari diharapkan semakin pintar dan cerdas. Pada akhirnya, guru hendaklah dapat lebih memberikan kontribusi bagi peningkatan mutu pendidikan dan pengajaran kepada muridmuridnya.

\section{PENINGKATAN KOMPETENSI GURU}

Kompetensi adalah kemampuan individu untuk melaksanakan suatu pekerjaan dengan benar dan memiliki keunggulan yang didasarkan pada hal-hal yang menyangkut pengetahuan (knowledge), keahlian (skill), dan sikap (attitude). Begitu pentingnya kompetensi ini membuat sistem perkembangannya bagi setiap lembaga/organisasi yang ingin sukses wajib dan harus dilakukan seluas-luasnya, lebih-lebih pada lembaga pendidikan seperti sekolah saat ini.

Pengertian lain dari kompetensi menurut Spencer dan Spencer (1993) : “an underlying characteristic of an individual that is causally related to criterion-referenced effective an/or superior performance in a job or situation". Dalam Undang-Undang ketenagakerjaan Nomor 13 Tahun 2003: kompetensi kerja adalah kemampuan kerja setiap individu yang mencakup aspek pengetahuan, keterampilan, dan sikap kerja yang sesuai dengan standar yang ditetapkan.

Secara umum peningkatan kompetensi guru diselenggarakan dengan menggunakan prinsip-prinsip seperti: a) Demokratis dan berkeadilan serta tidak diskriminatif dengan menjunjung tinggi hak asasi manusia nilai keagamaan, nilai kultural, dan kemajemukan bangsa, b) satu kesatuan yang sistemik dengan sistem terbuka dan multi makna, c) suatu proses pembudayaan dan pemberdayaan guru yang berlangsung sepanjang hayat, d) memberi keteladanan, membangun kemauan, dan mengembangkan kreativitas guru dalam proses pembelajaran, e) memberdayakan semua komponen masyarakat melalui peran serta dalam penyelenggaraan dan pengendalian mutu layanan pendidikan. Sedangkan, secara 
khusus program peningkatan kompetensi guru diselenggarakan dengan prinsip-prinsip seperti: ilmiah, relevan, sistematis, konsisten, aktual dan konstektual, fleksibel, demokratis, obyektif, komprehensif, memandirikan, profesional, bertahap, berjenjang, berkelanjutan, akuntabel, efektif dan efisien.

Untuk mengetahui kompetensi seorang guru, perlu dilakukan uji kompetensi. Uji kompetensi dimaksudkan untuk memperoleh informasi tentang kemampuan guru dalam melaksanakan proses pembelajaran. Berdasarkan hasil uji kompetensi, dirumuskan profil kompetensi guru menurut level tertentu yang sekaligus menentukan kelayakan dari guru tersebut. Dengan demikian, tujuan uji kompetensi adalah menilai dan menetapkan apakah guru sudah kompeten atau belum dilihat dari standar kompetensi yang diujikan.

Kegiatan peningkatan kompetensi guru memilki rasional dan pertimbangan empiris yang kuat, sehingga bisa dipertanggungjawabkan baik secara akademik, moral, maupun keprofesian. Dengan demikian, disamping hasil penilaian kinerja, uji kompetensi menjadi salah satu basis utama desain program peningkatan kompetensi guru. Uji kompetensi esensinya berfokus pada keempat kompetensi yang harus dimilkii oleh guru seperti yang telah dijelaskan sebelumnya yaitu kompetensi pedagogik, kepribadian, sosial dan kompetensi profesional.

\section{GURU PROFESIONAL}

Kesadaran untuk menghadirkan guru guru dan tenaga kependidikan yang profesional sebagai sumber daya utama pencerdas bangsa, barangkali sama tuanya dengan sejarah peradaban pendidikan. Berkaitan dengan penyediaan guru UU No. 14 Tahun 2005 tentang guru dan dosen dan Peraturan Pemerintah No. 74 Tahun 2008 tentang guru telah menggariskan bahwa penyediaan guru menjadi kewenangan lembaga pendidikan tenaga kependidikan. Menurut dua produk hukum ini, lembaga pendidikan tenaga kependidikan yang dimaksud adalah perguruan tinggi yang diberi tugas oleh pemerintah untuk menyelenggarakan program pengadaan guru pada pendidikan anak usia dini jalur pendidikan formal, pendidikan dasar, dan/atau pendidikan menengah, serta untuk menyelenggarakan dan mengembangkan ilmu kependidikan dan non kependidikan.

Guru adalah profesi yang terhormat. Howard M. Vollmer dan Donals L. Miills (1966) mengatakan bahwa profesi adalah sebuah jabatan yang memerlukan kemampuan intelektual khusus, yang diperoleh melalui kegiatan belajar dan pelatihan. Bertujuan untuk menguasai keterampilan atau keahlian dalam melayani atau memberikan nasehat pada orang lain, dengan memperoleh upah atau gaji dalam jumlah tertentu. 
Guru profesional memiliki arena khusus untuk berbagi minat, tujuan dan nilai-nilai profesional serta kemanusiaan mereka.. Dengan sikap dan sifat semacam itu, guru profesional memilki kemampuan melakukan profesionalisasi secara terus menerus, memotivasi diri, mendisiplinkan dan meregulasi diri, mengevaluasi diri, kesadaran diri, mengembangkan diri, berempati, menjalin hubungan yang efektif. Guru profesional adalah pembelajar sejati dan menjunjung tinggi kode etik dalam bekerja. Menurut Danim (2010) secara akademik guru profesional bercirikan sebagai berikut : 1) mumpuni kemampuan profesionalnya dan siap diuji atas kemampuannya itu, 2) memiliki kemampuan berintegrasi antar guru dan kelompok lain yang seprofesi dengan mereka melalui kontrak dan aliansi sosial, 3) melepaskan diri dari belenggu kekuasaan birokrasi, tanpa menghilangkan makna etika kerja dan tata santun berhubungan dengan atasannya, 4) memiliki rencana dan program pribadi untuk meningkatkan kompetensi, dan gemar melibatkan diri secara individual atau kelompok seminat untuk merangsang pertumbuhan diri, 5) berani dan mampu memberikan masukan kepada semua pihak dalam rangka perbaikan mutu pendidikan dan pembelajaran, termasuk dalam penyusunan kebijakan bidang pendidikan, 6) siap bekerja tanpa diatur, karena sudah bisa mengatur dan mendisiplinkan dirinya, 7) siap bekerja tanpa diseru ataupun diancam, karena sudah bisa memotivasi dan mengatur dirinya, 8) secara rutin melakukan evaluasi diri untuk mendapatkan umpan balik dalam perbaikan diri, 9) memiliki empati yang kuat, 10) mampu berkomunikasi secara efektif dengan siswa, kolega, komunitas sekolah dan masyarakat, 11) menjunjung tinggi etika kerja dan kaidahkaidah hubungan kerja, 12) menjunjung tinggi kode etik organisasi tempatnya bernaung, 13) memiliki kesetiaan (loyality) dan kepercayaan (trust), dalam makna tersebut mengakui keterkaitanya dengan orang lain dan tidak mementingkan diri sendiri, 15) adanya kebebasan diri dalam beraktualisasi melalui kegiatan lembaga-lembaga sosial dengan berbagai ragam perspektif.

\section{METODE PENELITIAN}

Penelitian ini termasuk dalam jenis penelitian kualitatif induktif. Menurut Cresswell (2008) “an inductive approach aimed at reducing the data into a manageable number of themes that adressed the concern of study”. Metode kualitatif bertolak dari pandangan fenomenologis, yang mana peneliti berusaha memahami arti peristiwa dan kaitankaitannya terhadap orang-orang biasa dalam situasi-situasi tertentu (Pattilima, 2011) (Emzir, 2011) (Bungin, 2008) (Moleong, 2002) (Budiman, 2002) (Patton, 1990) 
(Sugiyono, 2005) (Kristiawan dan Tobari, 2017). Dalam penelitian ini, peneliti berusaha menggali secara mendalam tentang apakah ada pengaruh tunjangan profesi guru terhadap peningkatan kompetensi guru-guru yang telah menerima tunjangan profesi tersebut di Sekolah Dasar (SD) Negeri 3 Rambutan Kabupaten Banyuasin, menganalisis berita, hasil penelitian dan teori-teori terkait dengan penelitian. Data dari SD Negeri 3 Rambutan Banyuasin, berita hasil penelitian dan teoriteori yang terkait dengan penelitian menjadi data primer dalam penelitian ini.

Objek dalam penelitian ini adalah guruguru Sekolah Dasar Negeri 3 Rambutan Kabupaten Banyuasin yang telah bersertifikat pendidik (sertifikasi) atau yang telah menerima tunjangan profesi guru (TPG), berita, hasil dan teori-teori yang terkait dengan penelitian tentang pengaruh tunjangan profesi terhadap peningkatan kompetensi guru. Peneliti juga melakukan wawancara langsung ke guru dan Kepala SD Negeri 3 Rambutan Banyuasin yang telah menerima tunjangan profesi/ TPG (sertifikasi).

Metode pengumpulan data yang digunakan dalam penelitian ini adalah observasi, wawancara, studi berita dan hasil penelitian dan teori-teori terkait tentang peningkatan kompetensi guru yang telah menerima tunjangan profesi. Menurut Sugiyono (2006), wawancara digunakan sebagai teknik pengumpulan data apabila peneliti ingin melakukan studi pendahuluan untuk menemukan permasalahan yang harus diteliti, dan juga apabila peneliti ingin mengetahui hal-hal dari responden yang lebih mendalam dan jumlah respondennya sedikit atau kecil. Sedangkan Observasi menurut Riduwan (2010) adalah pengamatan secara langsung ke objek penelitian untuk melihat dari dekat kegiatan yang dilakukan.

Dalam menganalisis data, peneliti meringkas data dalam bentuk yang mudah dipahami dan mudah ditafsirkan (Sukardi, 2004). Menurut Moleong (2007) aktivitas dalam analisis data kualitatif dilakukan secara interaktif dan berlangsung secara terus menerus pada setiap tahapan penelitian sehingga sampai tuntas, dan datanya sampai jenuh. Boghdan dan Biklen (1982) menyebutkan "analysis involves working with data, organizing it, breaking it into manageable units, synthesizing searching for patterms, discoveringwhat is important and what to be learned and deciding what you will tell the others".

\section{HASIL PENELITIAN DAN PEMBAHASAN}

Secara formal, guru harus memiliki derajat profesionalitas tertentu yang tercermin dari kompetensi, kemahiran, kecakapan atau keterampilan yang memenuhi standar mutu dan normal etik tertentu. Guru-guru yang 
memenuhi kriteria profesional inilah yang mampu menjalankan fungsi utamanya secara efektif dan efisien untuk mewujudkan proses pendidikan dan pembelajaran sejalan dengan tujuan pendidikan nasional, yakni mengembangkan potensi peserta didik agar menjadi manusia yang beriman dan bertakwa, berakhlak mulia, sehat, berilmu, cakap, kreatif, mandiri serta menjadi warga negara yang demokratis dan bertanggung jawab.

Guru Profesional dituntut oleh undangundang memiliki kualifikasi akademik tertentu dan empat kompetensi diantaranya kompetensi pedagogik, kepribadian, sosial dan profesional atau akademik. Program sertifikasi guru yang berdampak diberikannya sertifikat pendidik dan tunjangan profesi kepada guru yang telah memenuhi persyaratan merupakan pengakuan negara atas derajat keprofesionalan guru (Undang-Undang Nomor 14 Tahun 2005).

Berdasarkan hasil observasi pada tanggal 5 Januari 2017 dan wawancara pada tanggal 9 Januari 2017 dengan Kepala SD Negeri 3 Rambutan Banyuasin, Faridah, S.Pd dan 2 orang guru yang telah memilki sertifikat pendidik dan menerima tunjangan profesi, Nani Wijaya, S.Pd. M.Si dan Anan Kailani, S.Pd.SD, maka Pengaruh Tunjangan Profesi terhadap Peningkatan Kompetensi Guru di SD Negeri 3 Rambutan Banyuasin dapat dideskripsikan sebagai berikut : bahwa dengan adanya tunjangan profesi ini, peningkatan kompetensi guru dalam hal kepribadian, yakni semakin meningkatnya motivasi mengajar dan tanggung jawab para guru, hal ini dapat terlihat dari absensi kehadiran guru di sekolah, guru hadir lebih awal di sekolah dan mengajar tepat waktu di kelas. Dengan kata lain, adanya tunjangan profesi ini berpengaruh besar terhadap peningkatan kinerja guru-guru di SD Negeri 3 Rambutan Banyuasin ini. Dan dari sisi peningkatan kompetensi guru secara pedagogik dan profesional atau akademik, pengaruh tunjangan profesi ini membawa dampak guru menjadi termotivasi untuk belajar menggunakan IT untuk mendukung proses pembelajaran di kelas. Motivasi ini diawali dengan minat belajar guru akan IT yang tinggi yang ditunjukkan dengan adanya inisiatif dari guru-guru yang telah menerima tunjangan profesi ini untuk membeli perangkat IT seperti laptop, notebook dan infokus dengan uang tunjangan profesi yang diperolehnya secara pribadi. Dengan adanya perangkat IT ini, guru juga termotivasi mencari masukan dan referensi tentang bahan ajar, metode dan strategi belajar mengajar untuk diterapkan dan disampaikan kepada peserta didik (siswa) di kelas. Sehingga penguasaan guru tentang teori-teori belajar, prinsip-prinsip pembelajaran yang mendidik, pengembangan kurikulum sekolah dapat dilaksanakan dan diterapkan sesuai dengan 
karakteristik peserta didik di SD Negeri 3 Rambutan ini.

Selain dari yang dijelaskan di atas, secara umum peningkatan kompetensi guru penerima tunjangan profesi di SD Negeri 3 Rambutan Banyuasin ini, juga dapat dilihat dengan ditunjuk dan dipercayainya guru-guru SD Negeri 3 Rambutan Banyuasin ini pada tahun 2012 untuk melaksanakan Program Piloting Sekolah Dasar (Inklusi) oleh Dinas Pendidikan Kabupaten Banyuasin yang dikhususkan untuk memberikan pembelajaran bagi Anak-Anak Berkebutuhan Khusus (ABK), dengan sebelumnya guru-guru pelaksana program ini (didominasi oleh guru yang telah menerima tunjangan profesi) diberikan Pendidikan dan Latihan (DIKLAT) selama 4 minggu di Hotel Aryaduta, Palembang.

Peningkatan kompetensi Guru SD Negeri 3 Rambutan ini juga terlihat dari nilai hasil Uji Kompetensi Guru (UKG) tahun 2015 yang diraih oleh guru kelas 6, Anan Kailani, S.Pd.SD untuk Bidang Studi Guru SD Kelas Tinggi dengan perolehan nilai rata-rata dari 2 (dua) kompetensi yang diujikan (Pedagogik dan Profesional) dengan nilai 80. Dan dengan capaian nilai hasil UKG di atas standar nilai minimum (50) yang diharapkan tersebut, berdampak ditunjuknya Anan Kailani, S.Pd.SD untuk menjadi Instruktur Nasional (IN) bagi Guru Pembelajar (GP) Bidang Studi
Guru SD Kelas Tinggi untuk seluruh wilayah Kabupaten Banyuasin. Sebelumnya juga, untuk menjadi Instruktur Nasional (IN) ini diberikan pelatihan selama 10 hari di Hotel Beskip, Palembang. Selain itu, pada tahun 2016, guru kelas 6 lainnya, Nani Diana, S.Pd juga dipercaya oleh Dinas Pendidikan Kabupaten Banyuasin untuk menjadi Instruktur Kabupaten (IK) dalam Kegiatan Implementasi Pengembangan dan Pendampingan serta Evaluasi Kurikulum 2013 bagi Sekolah, Kepala Sekolah dan Guru Sasaran (GS) pelaksana kurikulum 2013 Cluster 1 Kabupaten Banyuasin. Dan tentunya dengan tugas tambahan menjadi Instruktur Nasional (IN) dan Instruktur Kabupaten (IK) tersebut, guru yang bersangkutan menerima uang transport tambahan yang nominalnya dirasa sudah lebih dari cukup dan point terpenting adalah guru tersebut dapat meningkatkan lagi kompetensi profesional akademiknya secara berkelanjutan dengan mengikuti pelatihan-pelatihan sebelumnya untuk mengembangkan profesinya.

\section{KESIMPULAN}

Berdasarkan hasil penelitian dan pembahasan dapat disimpulkan bahwa ada beberapa pengaruh positif dengan adanya Tunjangan Profesi Guru (TPG) terhadap peningkatan kompetensi guru di SD Negeri 3 Rambutan Banyuasin. Beberapa pengaruh 
positif ini antara lain : 1) Peningkatan

Kompetensi Kepribadian, yakni semakin meningkatnya motivasi mengajar dan tanggung jawab para guru dalam melaksanakan tugasnya. Hal ini dapat terlihat dari absensi kehadiran guru di sekolah, guru hadir lebih awal di sekolah dan mengajar tepat waktu di kelas. Dengan kata lain, adanya tunjangan profesi ini berpengaruh besar terhadap peningkatan kinerja guru-guru di SD Negeri 3 Rambutan Kabupaten Banyuasin ini, 2) Peningkatan Kompetensi Pedagogik dan Profesional atau Akademik, pengaruh tunjangan profesi terlihat dari adanya motivasi guru untuk belajar menggunakan IT untuk mendukung proses pembelajaran di kelas. Motivasi ini diawali dengan adanya inisiatif dari guru-guru untuk membeli perangkat IT seperti laptop, notebook dan infokus dengan uang tunjangan profesi yang diperolehnya secara pribadi. Dengan adanya perangkat IT ini, guru juga termotivasi mencari masukan dan referensi tentang bahan ajar, metode dan strategi belajar mengajar untuk diterapkan dan disampaikan kepada peserta didik (siswa) di kelas, 3) Secara umum peningkatan kompetensi juga dapat dilihat dengan ditunjuk dan dipercayainya guru-guru SD Negeri 3 Rambutan Banyuasin pada tahun 2012 untuk melaksanakan Program Piloting Sekolah Dasar (Inklusi) oleh Dinas Pendidikan Kabupaten Banyuasin yang dikhususkan untuk memberikan pembelajaran bagi Anak-Anak Berkebutuhan Khusus (ABK), 4) Secara khusus Peningkatan kompetensi Guru SD Negeri 3 Rambutan terlihat dari nilai hasil Uji Kompetensi Guru (UKG) tahun 2015 yang diraih oleh guru kelas 6, Anan Kailani, S.Pd.SD untuk Bidang Studi Guru SD Kelas Tinggi dengan perolehan nilai rata-rata dari 2 (dua) kompetensi yang diujikan (Pedagogik dan Profesional) dengan nilai 80. Dan dengan capaian nilai hasil UKG di atas standar nilai minimum (50) yang diharapkan tersebut, berdampak ditunjuknya Anan Kailani, S.Pd.SD untuk menjadi Instruktur Nasional (IN) bagi Guru Pembelajar (GP) Bidang Studi Guru SD Kelas Tinggi untuk seluruh wilayah Kabupaten Banyuasin. Dan juga di tahun 2016, guru kelas 6 lainnya, Nani Diana, S.Pd juga dipercaya oleh Dinas Pendidikan Kabupaten Banyuasin untuk menjadi Instruktur Kabupaten (IK) dalam Kegiatan Implementasi Pengembangan dan Pendampingan serta Evaluasi Kurikulum 2013 bagi Sekolah, Kepala Sekolah dan Guru Sasaran (GS) pelaksana kurikulum 2013 Cluster 1 Kabupaten Banyuasin

\section{DAFTAR PUSTAKA}

Bogdan, R and Biklen, SK. (1982). Qualitative Research For Education, an Introduction to Theory and Method. Boston: Allyn and Bacon. 
Budiman, Aris. (2002). Desain Penelitian, Pendekatan Kualitatif \& Kuantitatif. Jakarta: KIKI Press.

Bungin, M Burhan. (2008). Penelitian Kualitatif; Komunikasi, Ekonomi, Kebijakan Publik, dan Ilmu Sosial Lainnya. Jakarta: Kencana.

Cresswell, J.W. (2008). Educational Research: Planning, Conducting, and Evaluating Quantitative and Qualitative Research. New York, NY: Prentince Hall.

Emzir. (2011). Analisis Data: Metodologi Penellitian Kualitatif. Jakarta: Rajawali Press.

Danim, Sudarwan. (2010). Profesionalisasi dan Etika Profesi Guru. Bandung: Alfabeta.

Kamil Uszaman. (2014) Signifikasi Kompetensi Bagi Guru PAI. (online) http://kamiluszaman.blogspot.co.id/2014 /11/signifikasi-kompetensi-bagi-gurupai.html. Diakses tanggal 7 Januari 2017.

Kristiawan, M. dan Tobari. (2017). The Characteristics of Full Day School Based Elementary School. Transylvanian Review: Vol XXV, No. 14, 2017

Lyle M Spencer Jr. dan Signe M Spencer. (1993). Competence at work, New York Wiley, hal.9.

Moleong, Lexy J. (2002). Metodologi Penelitian Kualitatif. Bandung: Remaja Rosdakarya.

Patilima, Hamid. (2011). Metode Penelitian Kualitatif. Bandung: CV. Alfabeta.

Patton, Michail Quin. (1990). Qualitative Evaluation and Research Method. Newbury Park: Sage Publication.

Peraturan Pemerintah Nomor 19 tahun 2005 tentang Standar Nasional Pendidikan.
Peraturan Pemerintah Nomor 41 Tahun 2009 tentang Tunjangan Profesi Guru dan Dosen, Tunjangan Khusus Guru dan Dosen, serta Tunjangan Kehormatan Profesor, Pasal 7.

Peraturan Pemerintah Nomor 74 Tahun 2008 Tentang Guru.

Peraturan Menteri Keuangan No.164/PMK.05/2010 tentang Tata Cara Pembayaran Tunjangan Profesi Guru dan Dosen, Tunjangan Khusus Guru dan Dosen, serta Tunjangan Kehormatan Profesor, Pasal 9 ayat 1 .

Peraturan Menteri Pendidikan Nasional Nomor 72 tahun 2008.

Riduwan. (2010). Belajar Mudah Penelitian Untuk Guru, Karyawan dan Peneliti Pemula (Cetakan keenam). Bandung: Alfabeta.

Saroni, Muhammad. (2001). Personal Branding Guru. Yogyakarta: Ar-Ruzz Media.

Sugiyono. (2005). Memahami Penelitian Kualitatif. Bandung: Alfabeta.

Sugiyono. (2006). Metode Penelitian Kuantitatif dan Kualitatif dan $R \& D$ (Cetakan Kesatu). Bandung: Alfabeta.

Sumatera Ekspres. (2016). Opini: Momentum Hari Guru, oleh Tobari. 28 September 2016.

Undang-Undang Nomor 14 Tahun 2005 Tentang Guru dan Dosen.

Undang-Undang Nomor 20 Tahun 2003 Tentang Sistem Pendidikan Nasional.

Undang-Undang Ketenagakerjaan Nomor 13 Tahun 2003

Vollmer dan Mills. (1982). Profesionalization. Jossey Bass, New York. 
